\title{
The Evaluation of Values Education Project conducted by the Context of Nature Education
}

\author{
Hüseyin Çalışkan \\ Department of Science Education, Faculty of Education, Sakarya University, Hendek/Sakarya \\ 54300, Turkey \\ ORCID: 0000-0001-6849-1318
}

Yusuf Yildirım*

İnegöl Erdem Beyazıt Imam Hatip secondary school, Bursa, Turkey, 16400 ORCID: 0000-0003-0035-8443,

\section{Eda Demirhan}

Department of Special Education, Faculty of Education, Sakarya University, Turkey 54300 ORCID: 0000-0001-9414-0431

Article history

Received:

30.10 .2020

Received in revised form: 27.12.2020

Accepted:

12.01.2021

Key words:

Environmental education,

Nature education,

Value,

Values education,

Inclusive education.
The aim of this research is to evaluate the effect of the project titled "Youth with Values, a Responsible Society and a Clean Environment" conducted with secondary school students. The study group of the research consists of 9 inclusive students ( 3 girls, 6 boys) and 9 students with a high academic success ( 4 girls, 5 boys) making up a total of 18 secondary school students. The study was conducted within the framework of the embedded pattern from the mixed patterns, in which quantitative and qualitative research methods were handled together. In the study, while the "Attitude Scale towards Values" and the "Value Determination Survey" were used as the pre-test and post-test as quantitative data collection tools; the open-ended questionnaire, focus group meetings and the data gained from the diaries of the participants were used as qualitative data collection tools. According to the results the project increased their scores according to the last measurements in the scales of attitudes towards the values. also, a significant difference was determined in the sub-dimensions of "environment and nature", "responsibility", "cultural values" and in the overall total of the attitudes towards values scale. Examining the qualitative data of the current research, it was found out that students had fun, made new friends and learned many new things about the nature and environment during this project. Furthermore, groups' opinions about the contribution of the project were classified as "cognitive awareness", "emotional awareness" and "behavioral awareness".

\footnotetext{
*Correspondency: yusufyildirimakademik@gmail.com
} 


\section{Introduction}

Human can be a source of problems for society, nature, and humanity. It is now an indisputable fact that individuals who do not have awareness or sensitivity can be harmful effects on the values of the society that they live in, and on the natural environment. Attitudes that demonstrate a lack of awareness, are indifferent and negative about the environment are signs of being insensitive towards nature. It should be remembered that mankind is a part of the nature and in order to survive should show it the respect it deserves and take responsibility for its protection. Otherwise, various disasters, such as those experienced in Turkey in recent years including floods, erosion, acid rain and climate change will continue to threaten life.

In addition, the unconscious and excessive use of the internet and information technology (IT) can also be evaluated as an environmental threat as it could lead to a gradual decrease in human contact with nature (Aksoy \& Akpınar, 2012; Turgut \& Y1lmaz, 2010) and a decline in environmental sensitivity. Turkey is currently placed at 108 of 180 countries in the 2018 Environmental Performance Index (URL 1) which indicates it is not at a level expected for environmental protection. In this context, encouraging students to actively participate in environmental education at a young age including living-doing methods is important to prevent environmental problems (Yıldız, Sipahioğlu \& Yılmaz, 2013). Yörük and Şahinler (2013), point out that in nature education students should play an active role in their own learning process rather than being passive recipients. Furthermore, Nisbet, Zelenski and Murphy (2009) state that spending more time in nature and doing various activities has positive results on one's connection with nature.

Dikmenli (2017) says that nature education should incorporate the cognitive, affective and psycho-motor learning styles of individuals. In this sense one of the aims of the educational curriculum in Turkey is to nurture individuals to become environmentally friendly and literate (Ministry of National Education, 2018). However, after observing science classes, the topics of nature and the environment are not given sufficient importance which does not help to train environmentally literate individuals (Avcı, Su-Özenir, Kurt \& Atik, 2015; Oğurlu, Alkan, Ünal, Ersin \& Bayrak, 2013). Also, as stated by Oğurlu et al. (2013), the theoretical environmental education provided in schools is on its own insufficient. In this context, the Scientific and Technological Research Council of Turkey (TUBITAK) is supporting several studies to raise awareness of the environment by enabling students to take part in activities in a non-school learning environment and within the scope of the science and society program. After observing such projects, it is determined that they enable students to develop positive attitudes towards nature (Keçeci, Zengin \& Alan, 2019), increase their level of knowledge (Çabuk \& Çabuk, 2017), improve their awareness and sensitivity (Avc1 et al., 2015; Feyzioğlu, Özenoğlu Kiremit, Öztürk Samur \& Aladağ, 2012) and contribute to improving their environmental literacy levels (Akbaşl1, 2018).

Environmental education is not only a process of informing individuals but also an activity of internalization of the acquired knowledge and then demonstrating it as a behavior as necessary. It can be said that environmental issues are intertwined with individual and social beliefs, attitudes, and values (Laçin-Şimşek, 2004). Values are important in explaining people's behavior. It is values along with general principles and beliefs that define and guide behavior, but they are also regarded as the standards that enable judgment about whether certain actions are good or not (Halstead \& Taylor, 2000). To put this in another way, values are the basic beliefs that help one to distinguish good from bad and incorporate meaning and balance into people's lives which make it possible to live alongside others in society. Individuals internalize values and turn them into behavior bringing them to life. Accordingly, 
values education helps individuals to develop their own values which ensure personal and social development. As human behavior is shaped according to the values obtained, it is thought that an environment enriched education can provide the values necessary to maintain a healthy environment (Laçin-Şimşek, 2004).

People who lack or stray far from certain values can be a problem for society, nature, and humanity. It seems that individuals who lack certain values may deliberately or unknowingly damage themselves, their families or society, as well as the natural environment. All the teaching programs in Turkeynow include values relating to the natural environment such as cleanliness, a love of nature, and sensitivity to natural heritage. These are all desirable values that are directly and indirectly conveyed to students because it is thought that those who hold such values are more likely to behave responsibly towards nature and the environment. Today more than ever, it seems that the natural environment is exposed to human behavior and affected by human contact, hence individuals should learn basic values such as respect, love and sensitivity. It is becoming more important to raise conscious individuals who love nature, regard it as a heritage to be entrusted to future generations and who act accordingly. From examining the literature, it is observed that some researchers are becoming more aware of this because they included in their research such subjects: sensitivity to natural heritage (Ferretti \& Comino, 2015; Barton, Hine \& Pretty, 2009; Kato, 2006; Yanarateş \& Y1lmaz, 2020, Yıldırım, 2014), love of nature (İbret, Demirbaş \& Demir; 2019; Özhanc1, \& Y1lmaz, 2015; Turgut \& Y1lmaz, 2000), and environment education (Atasoy \& Ertürk, 2008; Williams \& Harvey, 2001; Tilbury, 1995).

The aim of the current study is to provide secondary students with the values of 'love of nature', 'cleanliness', 'responsibility' and 'sensitivity to natural heritage' through collaborative nature education activities. Peer education, where those students who learn faster take the responsibility of the teaching of the related concepts to their peers who learn more slowly (Mazur, 1997) helps students who learn faster to review their learning processes and habits. In this respect, Whitebread, Bingham, Grau, Pasternak \& Sangster (2007) express how peer supported teaching environments support meta-cognitive mechanisms in students. It is observed that this interactive learning method promotes interest and enhances student participation (James, 2006; Fagen, Crouch \& Mazur, 2002). Therefore, positive attainments such as peer solidarity, communication and socialization are expected to be achieved in the process of this study. In this aspect, the aim is to evaluate the effects of the values education project in the context of nature education on both groups of students. In sum, this study was conducted to find out the two following questions:

(1) Is there a statistically significant mean difference in effectiveness of the values education project on academically successful students and inclusive students' environmental attitude scale, values scale, and values questionnaire?

(2) How are the feelings and opinions of the academically successful students and inclusive students on the values education project?

\section{Method}

This study has been conducted using the embedded pattern framework which is a mixed design of both quantitative and qualitative research methods. Plano-Clark,HuddlestonCasas, Churchill, O'Neil Green \& Garrett (2008) note that embedded pattern studies are more useful and have more depth because qualitative data is included. The primary aim of the study is to examine the effects of environmental education activities on the values of students based 
on a single group pre-test and a post-test analysis, which is one of the quantitative research methods. Büyüköztürk, et al. (2010) say that by using this pattern measurements of the same subjects related to the dependent variable are gained as a pre-test and a post-test before the application. Therefore, in this context the role of the project process and activities in creating this effect is supported by the data obtained from the case study as one of the qualitative research methods. Merriam (2013) describes the case study as an in-depth description and analysis of a limited system where the concept of the system included in the definition reflects the 'situation to be examined'. Accordingly, the situation to be examined in the context of a study can be determined as the experiences of all of the participants' in the project process.

\section{Participants}

There are 18 participants in this study, comprising nine inclusive students and nine high achievers from six secondary schools in a small town in Turkey. The demographic information regarding the gender and grade levels of the participants is presented in Table 1.

Table 1. Demographic information about the participants

\begin{tabular}{lllll}
\hline \multicolumn{2}{l}{ Inclusive Students } & & Academically Successful Students & Total \\
\hline Gender & Male & 3 & 4 & 7 \\
& Female & 6 & 5 & 11 \\
Grade & 6th & 4 & 2 & 9 \\
& 7 th & 5 & 7 & 9 \\
\hline
\end{tabular}

In selecting participants for the project, the preference was to choose students from low socioeconomic backgrounds with no behavior problems, health issues, allergies or phobias which might prevent them from carrying out any of the nature activities. Accordingly, three female and six male full-time inclusion students with mild learning disabilities and/or mild mental disabilities were included in the study. The high achieving students were selected based on their year-end average end scores, and those with a weighted average of 90 and above were selected for participation.

\section{Data Collection Tools}

The 'Attitude Scale towards Values' and 'Value Determination Survey' are used in this study as a form of pre-test and post-test quantitative data collection tools. In addition, an open-ended questionnaire, focus group interviews were used as qualitative data.

\section{The Attitude Scale towards Values}

This scale was developed by Gömleksiz and Cüro (2011) and was applied to determine students' attitudes towards values. It consists of six sub-scales which are environment and nature, scientism, responsibility, cultural values, respect and patriotism. It also has a five-point Likert type categorization, using; 'totally', 'very', 'a little', 'very little', 'none' and consists of 24 items in total. The overall average of the scale Cronbach alpha reliability coefficient is determined as 0.93 . Information on the reliability studies of the scale and the reliability information of the research are given in Table 2. 
Table 2. The sub-scales'Cronbach alpha reliability coefficients

\begin{tabular}{lll}
\hline & Values of sub-scale & This study' values of sub-scale \\
\hline Environment and nature & 0.75 & 0.84 \\
Scientific attitude & 0.74 & 0.72 \\
Responsibility & 0.83 & 0.50 \\
Cultural values & 0.81 & 0.62 \\
Respect & 0.76 & 0.85 \\
Patriotism & 0.79 & 0.74 \\
\hline
\end{tabular}

\section{The Value Determination Survey}

This was formed by the researchers to determine the pre-project and post-project ideas of the participants concerning their values (love of nature, cleanliness, sensitivity to natural heritage, respect for different thoughts, responsibility). When developing this survey, the opinions of two different field experts from social studies education and science education, were sought. This survey consists of 5 items. For this survey, the participants evaluated; a) how much they possess these expressions of value, and b) how important the relevant value is based on a score of between one and five, each as a separate item (i.e., 1- I have no idea, 2- I have very little information, 3- I know it as a concept, 4- I can give examples from daily life, 5 - I have knowledge and apply it in daily life). The points that can be taken from the related survey vary from five to 25 for and each separately.

\section{The Open-ended Question Form}

Patton (2014) says that open-ended questions are important data collection tools that enable individuals to examine their experiences, feelings, and thoughts from the words they choose. Accordingly, three open-ended questions have been created by the researchers to reveal the participants' perspectives on the environment and nature before and after the project. The questions were primarily examined by three experts in the fields of environmental education, science education and values education who were lecturers at different universities. They were also shared with two students at similar grades who confirmed their comprehensibility.

\section{The Focus Group Interviews}

These are planned discussions organized to learn about the ideas of a certain group of students on a previously determined topic. The purpose of the focus group meetings is to reveal how participants perceive the situation instead of making statements about them (Krueger \& Casey, 2000). This makes it feasible to reveal opinions that are impossible to ascertain from one-on-one meetings or focus group discussions (Kitzinger, 1994). For this study, focus group discussions were hold to gain qualitative data about what the project means to the participants and to learn about their attitudes to the environment, nature, natural heritage, environmental awareness, love of nature, responsibilities towards the environment and environmental cleanliness. Thus, the focus group meetings were carried out separately with three environmental teams consisting of six students. The prepared questions for the focus group interviews were unstructured. There were seven questions in the pre-test process and ten in the post-test process (e.g., What does the natural environment mean to you?, How does it feel to be involved in this project/event? Why? What are the positive and negative aspects of this project/activities for you? Why? etc.). The focus group meetings lasted for about half an hour for each environmental team. During the meetings, all participants were allowed to express their views. 


\section{The Application Process}

This study was carried out between 25 June and 2 July 2019 and in keeping with the implementation process of the 'Youth with Values, a Responsible Society and a Clean Environment' project supported by Scientific and Technological Research Council of Turkey (TUBITAK) 4004 Nature Education and Science Schools. The aim is for participants to gain an awareness of and develop a positive attitude to the environment. This was to be achieved by group working in the context of environmental education and by participating in values education practices. The activities have been planned around the values of 'responsibility', 'cleanliness', 'sensitivity to natural heritage' and 'love of nature'. In total, 13 academics working in eight different universities and two teachers working in two different secondary schools have taken part in the project. It was conducted over eight days and comprised 17 different activities (Table 3). In addition, three teachers supported the project as process and activity consultants.

Table 3. Activity program of the project

\begin{tabular}{|c|c|}
\hline Days & Activities \\
\hline \multirow{3}{*}{25 June 2019} & Grow with love \\
\hline & I discover nature and my values \\
\hline & The effects of environmental pollution on human and environmental health \\
\hline \multirow{2}{*}{ 26 June 2019} & Entrepreneurial ideas \\
\hline & Cleanliness balance in nature (Oylat Thermal Springs) \\
\hline \multirow{2}{*}{27 June 2019} & Produce, pollute, clean (Çilek furniture) \\
\hline & Acid rains \\
\hline \multirow{2}{*}{28 June 2019} & Sections of forest life (Bursa forest museum) \\
\hline & Environmentalist Karagöz with Hacivat (Bursa Karagöz museum) \\
\hline 29 June 2019 & $\begin{array}{l}\text { Insensitive İbiş \& Sensitive Efendi - Learning love of the nature } \\
\text { From garbage to energy }\end{array}$ \\
\hline 27 June 2019 & $\begin{array}{l}\text { Different ideas, common feelings } \\
\text { Conversion to solid waste } \\
\text { I'm a flower. I will grow with love }\end{array}$ \\
\hline 1 July 2019 & $\begin{array}{l}\text { You take a garbage too } \\
\text { From garbage to home }\end{array}$ \\
\hline 2 July 2019 & I'm valuable with my gains \\
\hline
\end{tabular}

The project activities were planned to be performed in three groups. Each group was made up of three inclusion and three high achieving students. During the course of the project, the groups studied collaboratively, and one consultant teacher was assigned to each group to guide them. The activities were conducted in three ways - cognitively, affective and behaviourally due to the nature of knowledge and value. The events, photographs and information about the project is detailed at http://cevredegeregitimi.com/

\section{Data Analysis}

The quantitative data has been analyzed using the SPSS 22.0 statistical package. The level of significance is determined as $\mathrm{p} \leq 0.05$. The results of the Shapiro-Wilk test have been examined to determine whether the data provided normal assumptions and the results revealed an abnormal distribution ( $\mathrm{p}<0.05$ ). The skewness and kurtosis values were determined to be far from \pm 1.96 . Therefore, an analysis of the quantitative data was carried out using the Wilcoxon signed rank test, which is one of the non-parametric tests. The qualitative data obtained was analyzed using descriptive analysis. The data gathered from the study was analyzed in four stages: forming a frame for descriptive analysis, processing data according to the frame, and defining and interpreting the findings. Cognitive, affective and behavioral awareness titles were determined as categories in order to analyze the collected qualitative 
data. Qualitative data were analyzed descriptively in line with these categories. Codes that came out of the statements of the participants primarily were determined and the codes found afterwards were placed in the relevant categories. The responses of the participants were analyzed by two researchers of the study. In case of disagreement, researchers came together and reached a joint decision. In addition, Wolcott (1994) notes that descriptive analysis can provide direct quotations from research participants. For quotations, the participants were categorized as S6, S8 etc. because of ethical issues ( $S$ identifying the student and the number indicating the participant).

\section{Findings}

\section{Findings from the Quantitative Data}

The descriptive statistics relating to the participants' attitude scores on the environment, the scale of the values and the value expressions are provided in Table 4.

Table 4. Arithmetic means for the scores obtained from the scale tools

\begin{tabular}{|c|c|c|c|c|c|c|c|c|c|c|c|c|}
\hline & & & & & lusive $\mathrm{St}$ & dents & & $\begin{array}{l}\text { ademical } \\
\text { cessful }\end{array}$ & udents & Gen & & \\
\hline & & & & $\mathrm{N}$ & $\overline{\mathrm{X}}$ & ss & $\mathrm{N}$ & $\overline{\mathrm{X}}$ & ss & $\mathrm{N}$ & $\overline{\mathrm{X}}$ & ss \\
\hline & Respect & & Pretest & 9 & 14.55 & 4.12 & 9 & 17.88 & 1.76 & 18 & 16.22 & 3.52 \\
\hline & & & Posttest & 9 & 16.55 & 3.53 & 9 & 19.44 & 1.13 & 18 & 18.00 & 2.95 \\
\hline & Patriotism & & Pretest & 9 & 16.00 & 1.73 & 9 & 19.33 & 1.00 & 18 & 17.66 & 2.19 \\
\hline & & & Posttest & 9 & 17.11 & 2.75 & 9 & 19.44 & 1.33 & 18 & 18.27 & 2.42 \\
\hline & Environm & t \& & Pretest & 9 & 17.44 & 2.24 & 9 & 17.77 & 1.48 & 18 & 17.61 & 1.85 \\
\hline & Nature & & Posttest & 9 & 17.55 & 3.32 & 9 & 19.66 & 0.50 & 18 & 18.61 & 2.54 \\
\hline & Responsib & & Pretest & 9 & 18.77 & 3.07 & 9 & 20.88 & 1.69 & 18 & 19.83 & 2.64 \\
\hline & & & Posttest & 9 & 20.88 & 2.89 & 9 & 23.77 & 1.56 & 18 & 22.33 & 2.70 \\
\hline & Scientific & ttitude & Pretest & 9 & 10.55 & 3.39 & 9 & 12.55 & 1.50 & 18 & 11.55 & 2.74 \\
\hline & & & Posttest & 9 & 10.77 & 2.99 & 9 & 13.66 & 1.50 & 18 & 12.22 & 2.73 \\
\hline ల్లే & Cultural & lues & Pretest & 9 & 16.33 & 4.38 & 9 & 18.11 & 1.36 & 18 & 17.22 & 3.28 \\
\hline$\tilde{z}$ & & & Posttest & 9 & 17.11 & 2.31 & 9 & 19.44 & 1.01 & 18 & 18.27 & 2.10 \\
\hline$\frac{\Xi}{\pi}$ & Total & & Pretest & 9 & 93.66 & 16,74 & 9 & 106,55 & 6,94 & 18 & 100.11 & 14.09 \\
\hline & & & Posttest & 9 & 100.00 & 14,35 & 9 & 115,44 & 5,02 & 18 & 107.72 & 13.11 \\
\hline & & & Pretest & 9 & 22.66 & 3.32 & 9 & 22.44 & 2.51 & 18 & 22.55 & 2.85 \\
\hline & tion & & Posttest & 9 & 22.11 & 4.48 & 9 & 24.88 & .33 & 18 & 23.50 & 3.40 \\
\hline & tionnaire & wnerchi & Pretest & 9 & 20.22 & 1.56 & 9 & 18.56 & 5.00 & 18 & 19.38 & 3.70 \\
\hline & & Jwnership & Posttest & 9 & 21.67 & 3.87 & 9 & 23.66 & 1.50 & 18 & 22.66 & 3.03 \\
\hline
\end{tabular}

According to the information in Table 4, the inclusion students have fewer points in all the quantification tools than the high achieving students. It can also be seen that both groups of students have more points in the post-tests than in the pre-tests.

\section{Findings regarding the Students' Attitudes to Values}

The results of the Wilcoxon signed rank test carried out to evaluate the attitudes of high-achieving students to values are provided in Table 5. 
Table 5. Comparison of the scores of students with high academic success regarding the values scale with the Wilcoxon signed rank test

\begin{tabular}{|c|c|c|c|c|c|c|}
\hline & & $\mathrm{N}$ & Mean rank & Sum of ranks & $\mathrm{z}$ & $\mathrm{p}$ \\
\hline \multirow{3}{*}{ Respect } & Negative Ranks & 1 & 5.50 & 5.50 & -1.77 & 0.07 \\
\hline & Positive Ranks & 7 & 4.36 & 30.50 & & \\
\hline & Equal & 1 & & & & \\
\hline \multirow{3}{*}{ Patriotism } & Negative Ranks & 3 & 2.83 & 8.50 & -0.27 & 0.78 \\
\hline & Positive Ranks & 2 & 3.25 & 6.50 & & \\
\hline & Equal & 4 & & & & \\
\hline \multirow{3}{*}{$\begin{array}{l}\text { Nature \& } \\
\text { Environment }\end{array}$} & Negative Ranks & 1 & 2.00 & 2.00 & -2.25 & 0.02 \\
\hline & Positive Ranks & 7 & 4.86 & 34.00 & & \\
\hline & Equal & 1 & & & & \\
\hline \multirow{4}{*}{ Responsibility } & Negative Ranks & 1 & 1.50 & 1.50 & -2.51 & 0.01 \\
\hline & Positive Ranks & 8 & 5.44 & 43.50 & & \\
\hline & Equal & 0 & & & & \\
\hline & Negative Ranks & 1 & 6.00 & 6.00 & -1.72 & 0.08 \\
\hline \multirow{2}{*}{ Scientific attitude } & Positive Ranks & 7 & 4.29 & 30.00 & & \\
\hline & Equal & 1 & & & & \\
\hline \multirow[t]{4}{*}{ Cultural Values } & Negative Ranks & 1 & 2.50 & 2.50 & -1.98 & 0.04 \\
\hline & Positive Ranks & 6 & 4.25 & 25.50 & & \\
\hline & Equal & 2 & & & & \\
\hline & Negative Ranks & 1 & 3.00 & 3.00 & -2.11 & 0.03 \\
\hline \multirow[t]{2}{*}{ Total } & Positive Ranks & 7 & 4.71 & 33.00 & & \\
\hline & Equal & 1 & & & & \\
\hline
\end{tabular}

When comparing the pre-test post-test measurements of the high achieving students 'environment and nature $(\mathrm{z}=-2.25, \mathrm{p}<0.05)$ ', 'responsibility $(\mathrm{z}=-2.51, \mathrm{p}<0.05)$ ', 'cultural values $(\mathrm{z}=-1.98), \mathrm{p}<0.05)$ 'sub-dimensions and the overall total of the scale $(\mathrm{z}=-2.11, \mathrm{p}$ $<0.05)$ - a statistically significant difference was found. This difference is in favor of the posttests. Accordingly, it can be said that the nature education program set in the context of values education has a positive influence on high achieving students and their attitudes to values. The meaningful difference found in the sub-dimensions of environmental and nature and responsibility is compatible with the content of the project. As the project has been conducted within the framework of 'love of nature', 'sensitivity to natural heritage', 'cleanliness' and 'responsibility' values, it can be said to have met its target. An analysis of their averages is as follows: respect value pre-test (16.44), post-test (19.66); patriotism value pre-test (17.77), post-test (19.55); environment and nature pre-test (11.77), post-test (13.44); responsibility pre-test (19.11), post-test (26.44); scientific pre-test (11.77), post-test (13.44); cultural values pre-test (16.77), post-test (18.89) and total score pre-test (106.55), post-test (115.44). When the total score is examined within each sub-dimension, it is found that the post-test scores are higher than the pre-test scores. It can be said that these increases have their source in the environmental values training. When the pre-test and post-test measurements related to the scores of the inclusion students obtained from the sub-dimensions of the scale of values and the overall total are compared, there is no statistically significant difference ( $p>0.05)$.

\section{Findings from the Valuation Survey}

The results of the Wilcoxon signed rows test performed to evaluate the achievements from the value assessment survey, and which includes two different parts (the importance and ownership of the participants) are shown in Table 6. 
Table 6. Comparison of the scores of participants with the valuation questionnaire with the Wilcoxon signed rows test

\begin{tabular}{|c|c|c|c|c|c|c|c|}
\hline \multicolumn{3}{|c|}{ Valuation Questionnaire } & $\mathrm{N}$ & Row average & Row sum & $\mathrm{Z}$ & $\mathrm{p}$ \\
\hline \multirow{6}{*}{ 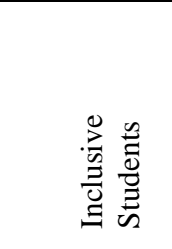 } & \multirow{3}{*}{ Valuation } & Negative Ranks & 2 & 7.00 & 14.00 & \multirow[t]{3}{*}{-1.01} & \multirow[t]{3}{*}{0.31} \\
\hline & & Positive Ranks & 7 & 4.43 & 31.00 & & \\
\hline & & Equal & 0 & & & & \\
\hline & \multirow{3}{*}{ Obtain } & Negative Ranks & 2 & 5.75 & 11.50 & \multirow[t]{3}{*}{-1.31} & \multirow[t]{3}{*}{0.18} \\
\hline & & Positive Ranks & 7 & 4.79 & 33.50 & & \\
\hline & & Equal & 0 & & & & \\
\hline \multirow{6}{*}{ 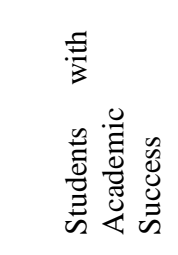 } & \multirow{3}{*}{ Valuation } & Negative Ranks & 1 & 2.00 & 2.00 & \multirow[t]{3}{*}{-1.51} & \multirow[t]{3}{*}{0.13} \\
\hline & & Positive Ranks & 4 & 3.25 & 13.00 & & \\
\hline & & Equal & 4 & & & & \\
\hline & \multirow{3}{*}{ Obtain } & Negative Ranks & 0 & 0.00 & 0.00 & \multirow[t]{3}{*}{-2.55} & \multirow[t]{3}{*}{0.01} \\
\hline & & Positive Ranks & 8 & 4.50 & 36.00 & & \\
\hline & & Equal & 1 & & & & \\
\hline
\end{tabular}

When comparing the pre-test and post-test measurements of the scores of the inclusion students from the valuation survey, no statistically significant difference is found in conceptions of both importance $(\mathrm{z}=-1.01, \mathrm{p}>0.05)$ and ownership $(\mathrm{z}=-1.31, \mathrm{p}>0.05)$. As for the high achieving students, there is no statistically significant difference for the valuation part of the measurements regarding the scores of the pre-test and post-tests $(\mathrm{z}=-1.51, \mathrm{p}>0.05)$. However, when the pre-test and post-test measurements related to ownership are compared, a statistically significant difference is found in favor of the post-test $(\mathrm{z}=-2.55, \mathrm{p}<0.05)$.

\section{Findings from the Qualitative Data}

\section{Findings from the Open-Ended Questions}

Table 7 lists the answers given by participants to the question: what are our responsibilities for our natural environment?

Table 7. The opinions of the participants on their duties to their natural environment.

\begin{tabular}{|c|c|c|c|c|c|}
\hline Group & Categories & Codes (before the project) & $f$ & Codes (after the Project) & \\
\hline \multirow{5}{*}{ 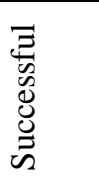 } & \multirow{8}{*}{ 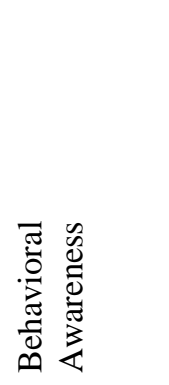 } & Protecting the environment & 5 & Protecting the environment & 5 \\
\hline & & Keeping it clean & 4 & Keeping it clean & 4 \\
\hline & & Not polluting & 4 & Not polluting & 4 \\
\hline & & Not throwing garbage warning people & 3 & Recycling & 3 \\
\hline & & Not damaging the environment & 3 & Not throwing garbage & 3 \\
\hline \multirow{3}{*}{ 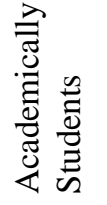 } & & & & Warning people & 3 \\
\hline & & & & Not wasting respect to nature & 3 \\
\hline & & & & To use renewable energy sources & 2 \\
\hline \multirow{6}{*}{ 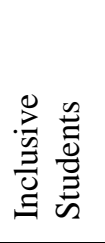 } & \multirow{6}{*}{ 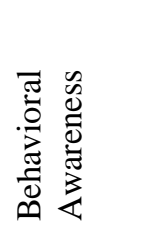 } & Protecting the environment & 5 & Not damaging the environment & 6 \\
\hline & & Not throwing garbage & 5 & Protecting the environment & 6 \\
\hline & & Not polluting nature & 4 & Not throwing garbage & 5 \\
\hline & & Picking up the garbage & 2 & Recycling & 4 \\
\hline & & Not wasting & 2 & Keeping environment clean & 2 \\
\hline & & Recycling & 1 & Not polluting & 1 \\
\hline
\end{tabular}

According to the Table 7, all of the students' statements could be grouped as the category of "behavioral awareness". Moreover, both groups of students express more ideas at the end of the project than they do at the outset. It can also be seen that the high achieving students gave more varied answers and mostly display the codes of 'protecting the environment $(\mathrm{f}=5)$ ', 
'keeping the environment clean ( $\mathrm{f}=4)$ ' and 'not polluting the environment $(\mathrm{f}=4)$ ' before and after the project. Prior to the project, the inclusion students expressed the codes of 'protecting the environment $(\mathrm{f}=5)^{\text {' }}$ and 'not throwing trash $(\mathrm{f}=5)$ ' but at the end of the project, they also stated the codes of 'not harming the environment $(\mathrm{f}=6)$ ' and 'protecting the environment $(\mathrm{f}=6)^{\prime}$.

"We went to Oylat today. We have seen how clean the waterfall is. We have learned that the dead creatures are eaten by microorganisms and mixed with the soil "(S9).

"We went to Oylat. We toured around. Then we came to woods. We talked about nature. We listened to the sounds of birds. And we understood that this pleasure would only be possible by keeping the environment clean "(S7).

Table 8 provides the answers given to the question - How did this project contribute to you being in this project?

Table 8. The ideas of the participants on the attainments during the project

\begin{tabular}{|c|c|c|c|c|}
\hline Group & Categories & Codes & $f$ & Total $f$ \\
\hline \multirow{8}{*}{$\begin{array}{l}\text { Academically Successful } \\
\text { Students }\end{array}$} & \multirow{3}{*}{ Cognitive Awareness } & Learning Recycling & 4 & \multirow{3}{*}{10} \\
\hline & & Comprehend the importance of nature & 4 & \\
\hline & & Raising a value of nature & 2 & \\
\hline & \multirow[t]{2}{*}{ Affective Awareness } & Responsibility for nature & 3 & \multirow{2}{*}{6} \\
\hline & & Sensitivity towards nature & 3 & \\
\hline & \multirow[t]{3}{*}{ Behavioral Awareness } & Necessity of warning people & 1 & \multirow{3}{*}{3} \\
\hline & & Keeping nature clean & 1 & \\
\hline & & Not throwing garbage & 1 & \\
\hline \multirow{7}{*}{ Inclusive Students } & \multirow{2}{*}{ Cognitive awareness } & Learning Recycling & 4 & \multirow{2}{*}{7} \\
\hline & & Comprehend the importance of nature & 3 & \\
\hline & \multirow[t]{4}{*}{ Behavioral Awareness } & Not throwing garbage & 2 & \multirow{4}{*}{5} \\
\hline & & Not polluting the nature & 1 & \\
\hline & & Keeping nature clean & 1 & \\
\hline & & The importance of teamwork & 1 & \\
\hline & Cognitive awareness & $\begin{array}{l}\text { Responsibility for nature } \\
\text { Sensitivity towards nature }\end{array}$ & $\begin{array}{l}2 \\
1\end{array}$ & 3 \\
\hline
\end{tabular}

The answers given in Table 8 to this open-ended question by both groups of students are stated in three different themes: cognitive awareness, affective awareness and behavioral awareness. The inclusion students stated the codes of 'recycling $(\mathrm{f}=4)$ ' and the 'importance of the environment $(\mathrm{f}=4)$ ' the most; and the high achieving students displayed the codes of 'recycling ( $\mathrm{f}=4)$ ' and 'the importance of the environment $(\mathrm{f}=3)$ ' the most.

"We need to keep the natural environment clean for living and plants to survive. Because we are a living being, too. If the environment is filthy, for example, then, our nature is polluted by factory fumes and we are damaged by it. Other creatures are also being damaged. We must keep nature clean for future generations "(S8).

"The place where people will eventually come back is nature. For example, people cannot get fresh air in İnegöl. Now, too many people started to throw garbage on the ground. But if we protect the nature, and love it; if we seed plants and make them grow, then our habitat will be nature again "(S14).

"We gained some important information in the Forest Museum. Then, we watched Karagoz and Hacivat Shadow Play. We learned that we shouldn't pollute the nature and harm other living beings in both of them"(S9). 


\section{Findings from the Focus Group Interviews}

Based on the data obtained from the focus group interviews, the participants' opinions about the contributions of the project are provided in Table 9.

Table 9. The participants' ideas on the contribution of the Project

\begin{tabular}{llll}
\hline Categories & Codes & $f$ & Total $f$ \\
\hline \multirow{3}{*}{ Cognitive Awareness } & Learning recycling & 9 & 21 \\
& Learning types of wastes & 7 & 3 \\
& Learning how to protect nature & 2 & \\
Affective Awareness & Learning about nature & 9 & 13 \\
& Sensitivity to natural environment & 3 & 1 \\
Behavioral Awareness & Gaining love of nature & 5 & 13 \\
& Realizing our responsibilities & 4 & 4 \\
\hline
\end{tabular}

The participants' opinions about the contributions of the project were collected under three different themes: 'cognitive awareness', 'affective awareness' and 'behavioral awareness'. Examples of some of the participants' opinions are as follows:

"We need to keep the natural environment clean for living in it and for plants to survive. Because we are living beings too. If the environment is filthy, for example, if our nature is polluted by factory fumes, we can be damaged by it. Other creatures are also being damaged. We must keep the nature clean for future generations" (S8).

"We learned some important things at the Forest Museum. Then, we watched a Karagoz and Hacivat Shadow Play. From these, we learned that we shouldn't pollute nature or harm other living beings" (S9).

The opinions of the students regarding the participation of students with different academic characteristics working together on this project are provided in Table 10.

Table 10. The feelings of the inclusive students and the academically successful students on being together in this project.

\begin{tabular}{|c|c|c|c|c|}
\hline \multicolumn{2}{|c|}{ Codes (before the project) } & $f$ & Codes (after the project) & $f$ \\
\hline \multirow{4}{*}{ 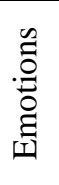 } & Happy & 9 & Happy & 10 \\
\hline & Excited & 2 & Nice & 4 \\
\hline & Good & 2 & Good & 4 \\
\hline & Proud & 1 & Excited & 3 \\
\hline \multirow{9}{*}{$\begin{array}{l}\tilde{0} \\
\tilde{\Xi} \\
\tilde{\Xi} \\
\simeq\end{array}$} & Protecting the environment & 7 & Gaining sensitivity for nature & 7 \\
\hline & $\begin{array}{l}\text { Learning new things } \\
\text { environment }\end{array}$ & about 4 & Learning new things about natural environment & 6 \\
\hline & Conveying to others & 2 & Learning new things about recycling & 5 \\
\hline & Taking responsibility & 1 & Awareness towards nature & 4 \\
\hline & Being in nature & 1 & Learning by having fun & 3 \\
\hline & Meeting new friends & 1 & Reflecting on my life & 2 \\
\hline & & & Conveying others & 1 \\
\hline & & & Realizing my responsibilities & 1 \\
\hline & & & Meeting new friends & 1 \\
\hline
\end{tabular}

When examining the participants' feelings about the project, it is seen that both before and after the project the most frequently repeated code is the 'happy' code. From their pre-project statements about the reasons for these feelings, the codes of 'protecting the environment 
$(\mathrm{f}=7)$ ' and 'learning new things about the environment $(\mathrm{f}=4)$ ' are used by participants most frequently. Regarding their opinions of the project, it is seen that the codes of 'acquiring sensitivity towards the environment $(\mathrm{f}=7)$ ', 'learning new things with nature $(\mathrm{f}=6)$ ' and 'learning new things about recycling $(\mathrm{f}=5)$ ' are their most expressed ideas. Examples of participants' quotations are given below:

"Sir, I am happy and a little excited. Because, we will learn new things and I like learning things a lot. That is why I am so happy and excited" (S3).

"We are happy. Because we will learn about keeping the environment clean. We will explain it to our friends and parents and this way the ideas will spread" (S6.)

When the participants' focus group interviews are examined, it can be seen that they express positive feelings about their academic and emotional achievements.

\section{Conclusion, Discussion and Recommendations}

The aim of this research is to evaluate the effects of the values education project conducted in the context of nature education on both inclusive and academically successful students. Quantitative and qualitative data collection tools have been used for the assessment. It is found that the post-test scores of all participants increased compared to the pre-test scores in findings from all the quantitative measurement tools.

It is determined that the academically successful students received high scores from the values scale in favor of the post-tests in the sub-dimensions of 'responsibility' and 'cultural values' and in the overall total of the scale. According to this result, it can be said that the project positively affected their values. Despite an increase in the scores of the inclusive students in favor of the post-tests in general and its sub-dimensions, there is no statistically significant difference between the pre- and post-test results. Similarly, after analyzing the results from the valuation questionnaire, it is seen that the scores achieved by the inclusive students both in the 'importance' and 'ownership' dimensions do not differ statistically. However, when the scores of the academically successful students from the valuation questionnaire are examined, while there is no statistically significant difference in the 'giving importance' sub-dimension; there is a statistically significant difference in the 'ownership' sub-dimension in favor of the last application. Accordingly, in the context of the statements from the valuation survey, it can be said that the project positively contributes to the academically successful students in terms of their love of nature, cleanliness, sensitivity to natural heritage, respect for different thoughts and having responsibility values. When considering the fact that the basic subjects emphasized during the project are the 'love of nature', 'sensitivity to natural heritage', 'cleanliness' and 'responsibility' values it can be said that the project has been successful in its aim. In a study conducted by Özdemir (2010), it is seen that by the end of the project students have gained environmental values. Students are expected to internalize environmental values during training which are based on their experience of nature. Dervişoğlu (2010) expresses how the values gained indirectly affect environmentalist behavior. Bögeholz (2006) states that individuals who have contact with their environment will develop values related to nature. Similarly, Dresner and Mary (1994) say that it is necessary to keep in touch with the environment for the development of naturerelated values. These expressions support applied nature education programs for developing environmental values in students.

Although progress has been observed in the inclusive students during the research, it is 
determined that in general they have shown less improvement than their peers. Inclusion students and their normally developing peers differ academically from childhood (Koch, Özdemir \& Akkose, 2014), and it is frequently stated in the literature that inclusive students learn more slowly than their peers (Sanır, 2009). Considering that such students have slower perception speeds than their peers and need more repetition, it is thought to be effective to plan projects for them over a longer period of time in order to obtain the stated aims. In a study with secondary school students, Y1ldirım (2019), focuses on the idea of a longer duration in order for the values education program to be effective.

When examining the answers to the open-ended questions, it is found that both the inclusive students and the academically successful students express more views at the end of the project than they do at the outset. It is determined that the academically successful students give more varied answers at the end of the project. Observing one of the open-ended questions about responsibilities towards nature, it can be seen that high-achieving students frequently indicate the codes for protecting the environment, keeping the environment clean and not polluting the environment both before and after the project. While before the project, the inclusive students state the codes for protecting the environment and not throwing trash the most; at the end of the project, they expressed the codes for not damaging the environment and protecting the environment. Therefore, it can also be said that these students adopt more of the values desired to be gained at the beginning of the project such as a love of nature, sensitivity towards natural heritage, responsibility towards nature and respect for nature. Bögeholz (2006) and Dresner and Mary (1994) concluded that experiences related to environment lead to develop values about the nature. In addition, Nisbet, Zelenski and Murphy (2009) concluded that spending more time in nature has positive results on one's connection with nature. Thus, these effects can be seen as a reason for producing more ideas at the end of the project by the participants. When the participants' feelings about being in the project are examined, it is found that the 'happiness' code is stated the most by both groups both before and after the project. In addition, the academically successful students state the codes for 'making new friends is good' before the project and at the end of the project, they state the codes for 'learning new things', 'making new friends' and 'being an environmentally sensitive individual' the most. Accordingly, it can be said that the project makes a positive contribution towards the socialization of the participants. In accordance with this study, Palmberg and Kuru (2000) state that nature-based education has positive effects on students' social relations. In this study, both groups of students say they have made new friends.

The responses the participants give about their contribution to the project are collected under the themes of 'cognitive awareness', 'affective awareness' and 'behavioral awareness' for both groups of students. Similar results were found in the focus group interviews and it is determined that the code for 'learning recycling' is the most frequently stated code by all participants in both the questionnaires and focus groups. Regarding the theme of affective awareness in the open-ended question, 'responsibility towards the environment' was the most frequently repeated code; and in the focus group interviews, 'sensitivity to the natural environment' is found to be the most frequently repeated code. In the context of behavioral awareness, it is found that inclusive students state the codes for 'not throwing trash' in the open-ended questions and those high achieving students state the code for 'the necessity to warn those around us'. In the emotional awareness theme in the focus group interviews, the code for 'behaving as a conscious individual' stands out. This means that the results obtained in the research processes are consistent with each other. Eventually, education is expected to be realized by integrating and complementing cognitive, affective, and psycho-motor domains. Similarly, it is believed that it is beneficial to complete these three dimensions of 
values education as the literature says that values education consists of cognition, emotion and behavior dimensions (Demir, 2018; İşcan \& Senemoğlu, 2009). Dresner and Mary (1994) find that students learn more about environmental values in locations where they are more familiar with the nature and ecological systems, and groups actively involved in environmental activities show significant changes in attitudes and behavior. In the current study, both groups of students have had their awareness raised most about 'recycling' and 'the importance of the environment'. Haluza and Delay (2001) state that real life experiences in natural environments significantly contribute to the development of environmental behavior. Özdemir (2010) says that students display responsible behavior towards their environments when motivated by experiences in nature. Oğurlu et al. (2013) also express how projects make it easier for individuals to turn information into behavior. Feyzioğlu et al. (2012) mentions how students' sensitivity and awareness towards their natural environments, environmental pollution and living species have been raised by their project. Along with these reactions, individuals are informed by observing their environment which leads them to the decision stage related to behavior development which produces a certain conclusion.

In the other results from the focus group interviews, 'being happy' is the feeling most expressed by the participants about the project. While expressing the reasons for their happiness as 'protecting the environment' and 'learning new things about the environment' before the project; at the end of the project, they also mention 'gaining sensitivity towards the environment', learning new things about nature' and 'learning new things about recycling'. In the conclusion of the 'Our Sea Mediterranean Project' carried out by Avc1 et al. (2015), it is determined that students' sensitivity towards the environment increases. Likewise, Kals, Schumacher and Montada (1999) determine that environmental education, which is mainly based on experience in nature, influences students' affective affinity, interest and behavior towards nature.

The learning outcomes of the inclusive students are important for other studies. In the current study they mostly mention how they have had fun and socialized with their peers during the project. Demirhan (2018), concludes that participants focus more on their social achievements at the end of the project. At the conclusion of the TÜBITAK 4004 project conducted by Hirça (2013), it is stated that the students learn by having fun and obtain the ability to work with groups. In the 'Nature Education IV in Isparta Protected Natural Areas IV' project carried out by Oğurlu (2016) it is also found that the students learn by having fun. Considering the fact that the main purpose of inclusive education is to meet the social and emotional needs of students with disabilities (Sucuoğlu \& Özokçu, 2005), it can be said that the socialization of both groups of students is one of the most important achievements of the current project. Inclusive education practices are a matter of great importance for children with special needs for experiencing and learning new social skills in environments with a range of peers. In this research, it can be regarded as an intended result for students to indicate and express how they have had the opportunity to have fun and learn together with their peers. With that being said, the participation of such a small number of students in this study and the use of paper-pencil tests as a measurement tool can be expressed as a limitation. In addition, the significant difference in the perception speeds of the participants can be considered negative in terms of group dynamics.

In conclusion, the high-test scores gained by all participants from the quantitative measurement tools compared to the pre-test results help to conclude that the project makes a positive contribution in terms of environmental attitudes and environmental value gains. It is observed that for the academically successful students especially, their scores for the values of 
environment and nature, responsibility and culture differ significantly on the value scale in favor of the post-tests. In addition, in the valuation survey, they obtain high scores in favor of the post-tests in terms of having the relevant value within the context of the project. Qualitatively, it can be said that the codes repeated in various measurement tools such as those for 'protecting the environment', 'not throwing trash', 'responsibility to the environment' and 'learning to recycle', support the quantitative results. Furthermore, all the participants state that they felt happy, had fun and socialized, which can be interpreted as an important outcome of the project.

The following recommendations are presented based on the study findings:

- It is suggested that future projects should be conducted with both talented and academically successful students, since the points achieved by the high achievers in this study are generally higher than those of the inclusive students.

- It is suggested that for future projects for inclusive students more than one repetitive activity related to the same target should be included and that they should be planned to take place over a longer term.

\section{References}

Akbaşl1, S. (2018). The evaluation of nature education training. International Online Journal of Education and Teaching (IOJET), 5(2), 295-311. http://iojet.org/index.php/ IOJET/article/view/385/236

Aksoy, Y., \& Akpınar, A. (2012). A research about public green area use and green area demand in İstanbul Fatih district. Istanbul Commerce University Journal of Science, 20, 81-96. http://dergipark.org.tr/en/download/article-file/199585

Atasoy, E., \& Ertürk, H. (2008). A field study about environmental knowledge and attidudes of elementary school students. Erzincan University Journal of Education Faculty, 10(1), 105-122. http://dergipark.org.tr/en/download/article-file/67727

Avc1, E., Su-Özenir, Ö. S., Kurt, M., \& Atik, S. (2015). Assessment of "Bizim Deniz Akdeniz" project planned for secondary school students financed by TUBITAK under 4004 Nature and Science Schools Program. Amasya Education Journal, 4(2), 312333. http://dergipark.org.tr/en/download/article-file/234050

Barton, J., Hine, R., \& Pretty, J. (2009). The health benefits of walking in greenspaces of high natural and heritage value. Journal of Integrative Environmental Sciences, 6(4), 261278. https://dx.doi.org/10.1080/19438150903378425.

Bögeholz, S. (2006). Nature experience and its importance for environmental knowledge, values and action: Recent German empirical contributions. Environmental Education Research. 12 (1), 65-84. https://dx.doi.org/10.1080/13504620500526529.

Büyüköztürk, Ş., Çakmak, E. K., Akgün, Ö. E., Karadeniz, Ş. \& Demirel, F. (2016). Scientific research methods. Pegem A Puplishing.

Çabuk, M. \& Çabuk, F. U. (2017). Investigation of efficiency of the project entitled "protect the environment with green chemistry" on preschool children's knowledge level about the environment. Journal of The Institute of Education Sciences Dumlupinar University, 1(1), 64-74. http://dergipark.org.tr/en/download/article-file/469761

Demir, F. (2018). Values education in life-science course according to values teaching approache [Unpublished doctoral dissertation]. İnönü University. 
Demirhan İşcan, C. \& Senemoğlu, N. (2009). Effectiveness of values education curriculum for fourth Grades. Education and Science, 34 (153), 1-14. http://egitimvebilim.ted.org.tr/index.php/EB/article/viewFile/556/57

Demirhan, E. (2018). Opinions of gifted students and prospective teachers on nature education program based on mentoring approach. Inönü University Journal of the Faculty of Education, 19 (3), 175-188. https://dx.doi.org/10.17679/inuefd.483536.

Dervişoğlu, S. (2010). Unıversity students' value orıentatıons toward livıng species. $H$. U. Journal of Education, 39, 132-141. http://dergipark.org.tr/en/download/articlefile/87462.

Dikmenli, Y. (2017). Preservice teachers' perception levels concerning consumer environmental consciousness. Journal of Education in Sclence Environment and Health, 3(2), 157-164. https://dx.doi.org/10.21891/jeseh.326741.

Dresner, M., \& Gill, M. (1994). Environmental education at summer nature camp. The Journal of Environmental Education, 25 (3), 35-41. https://dx.doi.org/10.1080/00958964.1994.9941956.

Fagen, A. P., Crouch, C. H., \& Mazur, E. (2002). Peer instruction: Results from a range of classrooms. The Physics Teacher, 40(4), 206-209. https://dx.doi.org/ 10.1119/1.1474140.

Ferretti, V., \& Comino, E. (2015). An integrated framework to assess complex cultural and natural heritage systems with Multi-Attribute Value Theory. Journal of Cultural Heritage, 16(5), 688-697. https://dx.doi.org/10.1016/j.culher.2015.01.007.

Feyzioğlu, B., Özenoğlu Kiremit, H., Öztürk Samur, A. \& Aladağ, E. (2012). YIBO’S are thinking scientifically in natural environment. Journal of Research in Education and Teaching, 1 (4), 65-74. https://www.researchgate.net/profile/Ayse_Oeztuerk_Samur/ publication/327108786_Yibolar_Dogal_Ortamda_Bilimsel_Dusunuyor/links/5b79c87 4299bf1d5a716ae37/Yibolar-Dogal-Ortamda-Bilimsel-Duesuenueyor.pdf

Gömleksiz, M. N. ve Cüro, E. (2011). An Assessment of students' attitudes towards values in Social Studies curriculum. International Journal of Human Sciences, 8 (1), 95-134. https://www.j-humansciences.com/ojs/index.php/IJHS/article/view/1299.

Halstead, J. M., \& Taylor, M. J. (2000). Learning and teaching about values: A review of recent research. Cambridge Journal of Education, 30 (2), 169-202. https://dx.doi.org/10.1080/713657146.

Haluza-Delay, R. (2001). Nothing here to care about: participant constructions of nature following a 12-day wilderness program. The Journal of Environmental Education, 32 (4), 43-https://doi.org/10.1080/00958960109598662

Hirça, N. (2013). Summer science camp experiences of gifted students. Journal of Gifted Education Research, 1(1), 22-30. http://www.acarindex.com/dosyalar/ makale/acarindex-1423937373.pdf

İbret, B. Ü., Demirbaş, İ., \& Demir, F. B. (2019). Primary school 4th grade students to gain responsibility for natural environment with alternative activities. Cumhuriyet International Journal of Education, 8(1), 258- 258-280. http://dx.doi.org/10.30703/cije.474570

James, M. C. (2006). The effect of grading incentive on student discourse in peer instruction. American Journal of Physics, 74(8), 689-691. https://dx.doi.org/ 10.1119/1.2198887.

Kals, E., Schumacher, D. \& Montada, L. (1999) Emotional affinity toward nature as amotivational basis to protect nature. Environment \& Behavior, 31(2), 178-202. https://dx.doi.org/10.1177/00139169921972056.

Kato, K. (2006). Community, connection and conservation: Intangible cultural values in Natural Heritage - the case of Shirakami-sanchi World Heritage Area. International 
journal of heritage studies, 12 (5), 458-473. https://dx.doi.org/10.1080/ 13527250600821670.

Keçeci, G, Kırbağ Zegin, F., \& Alan, B. (2019). The effect of the project "Little scientists explore Elaziğ Hazar Lake ecosystem“ by TÜBİTAK 4004 on the environmental attitudes of secondary school students. Journal of the Human and Social Sciences Researches, 8 (1), 41-63. http://www.itobiad.com/issue/43055/482979.

Kitzinger, J. (1994). The methodology of focus groups: The importance of interaction between research participants. Sociology of Health \& Illness, 16 (1), 103-121. https://dx.doi.org/10.1111/1467-9566.ep11347023.

Koch, K. R., Ozdemir, O., \& Cem Akkose, M. (2014). Enhancing early intervention services for children with Special Needs in the Middle East: A Turkish initiative. International Journal of Early Childhood Special Education,6(1). 143-150. https://eae.anadolu.edu.tr/resources/assets/upload/publication/20141112234546_mkl.p df

Krueger, R. A., \& Casey, M. A. (2000). Focus groups: A practical guide for applied research. (3rd edition). Sage.

Laçin-Şimşek, C. (2004). Ethical and aesthetic values in environmental education in scrence education curriculum and textbooks. Journal of Values Education , 2 (7 ve 8), 127 146. http://dergipark.org.tr/en/pub/ded/issue/36881/312464.

Mazur, E. (1997). Peer instruction - a users manual. Pearson.

MoNE (2018). Social studies curriculum (4, 5, 6. and 7. classes). TTKB Publications.

Merriam, S. B. (2013). Qualitative research: a guide to design and implementation (S. Turan, Trans.; 3rd ed.) Nobel Publishing. (Original work published 1953)

Nisbet, E. K., Zelenski, J. M., \& Murphy, S. A. (2009). The nature relatedness scale: Linking individuals' connection with nature to environmental concern and behavior. Environment and behavior, 41(5), 715-740. https://dx.doi.org/10.1177 \%2F0013916508318748.

Oğurlu, İ., Alkan, H., Ünal, Y., Ersin, M. Ö., \& Bayrak, H. (2013, June). Contributions of environment and nature training to geography education: IDE projects case study. Paper presented 3rd International Geography Symposium - Geomed (pp. 498-508), Antalya,

Turkey. http://web.deu.edu.tr/geomed/proceedings/download/048_GeoMed_2013_Proceedings 498-508.pdf

Özdemir, O. (2010). The effects of nature-based environmental education on environmental perception and behavior of primary school students. PAU Journal of Education, 27(27), 125-138. http://dergipark.org.tr/en/download/article-file/114641.

Özhanc1, E., \& Y1lmaz, H. (2015). Value of the love of nature (nature conservation and making use of it) and landscape architecture education. Journal of Tekirdag Agricultural Faculty, 12 (1), 39-45

Palmberg, I. E., \& Kuru, J. (2000). Outdoor activities as a basis for environmental responsibility. The Journal of Environmental Education, 31(4), 3236. https://dx.doi.org/10.1080/00958960009598649.

Patton, Q. M. (2014). Qualitative research and evaluation methods (M. Bütün, \& S. B. Demir, Trans.). PegemA Publishing. (Original work published 2008)

Plano-Clark, V. L., Huddleston-Casas, C. A., Churchill, S. L., O'Neil Green, D., \& Garrett, A. L. (2008). Mixed methods approaches in family science research. Journal of Family Issues, 29(11), 1543-1566. https://digitalcommons.unl.edu/cgi/viewcontent.cgi ?article $=1080 \&$ context $=$ edpsychpapers 
Sanır, H. (2009). Evaluation of the problems of the students who are in inclusive education in academic learning according to teacher and family opinions. [Unpublished master's thesis]. Selçuk University.

Sucuoğlu, B., \& Özokçu, O. (2005). Social skills of mainstreamed students evaluation of. Ankara University Faculty of Educational Sciences Journal of Special Education, 6 (01), 41-65. https://doi.org/10.1501/Ozlegt_0000000086

Tilbury, D. (1995). Environmental education for sustainability: Defining the new focus of environmental education in the 1990s. Environmental Education Research, 1(2), 195212. https://dx.doi.org/10.1080/1350462950010206.

Turgut, H., \& Y1lmaz, S. (2010, May). Buıldıng ecology-based playgrounds for kıds. Paper presented III. National Black Sea Forestry Congress (pp. 1618-1630), Artvin, Turkey. http://karok3.artvin.edu.tr/IV.html

URL 1. https://epi.envirocenter.yale.edu/epi-topline?country=turkey

Whitebread, D., Bingham, S., Grau, V., Pasternak, D. P., \& Sangster, C. (2007). Development of metacognition and self-regulated learning in young children: Role of collaborative and peer-assisted learning. Journal of Cognitive Education and Psychology, 6(3), 433455. https://dx.doi.org/10.1891/194589507787382043.

Williams, K., \& Harvey, D. (2001). Transcendent experience in forest environments. Journal of Environmental Psychology,21(3), 249-260. https://dx.doi.org/10.1006/ jevp.2001.0204.

Wolcott, H. F. (1994). Transforming qualitative data: Description, analysis, and interpretation. Sage.

Yanarateş, E. \& Y1lmaz, A. (2020). Öğretmen adaylarinin "çevre duyarliliği”" kavramina yönelik metaforik algilari. Gazi Üniversitesi Gazi Eğitim Fakültesi Dergisi, 40(3), 1019-1050.

Yıldırım, A. \& Şimşek, H. (2008). Qualitative research methods in the social sciences. Ankara: Seçkin Publishing.

Y1ldirım, Y. (2014). Analysis of moral maturity levels and social attitudes of the 5th and 6th grades of secondary school [Unpublished master tesis]. Erzincan University

Y1ldırım, Y. (2019). The effect of outdoor school activity based values education programme on students' effective citizenship values [Unpublished doctoral dissertation]. Sakarya University

Yıldız, K., Sipahioğlu, Ş., \& Yılmaz, M. (2013). Environmental science and education. Ankara: Gündüz Eğitim Publishing.

Yörük, A., \& Şahinler, N. (2013). Potential effects of global warming on the honey bee. Uludag Bee Journal,13 (2), 79-87. http://dergipark.org.tr/en/download/articlefile/409325. 